\title{
Clinical characteristics and outcomes of bacteraemic melioidosis in a teaching hospital in a northeastern state of Malaysia: a five-year review
}

\author{
Zakuan Zainy Deris ${ }^{1}$, Habsah Hasan ${ }^{2}$ and Mohd Noor Siti Suraiya ${ }^{1}$ \\ ${ }^{1}$ Department of Medical Microbiology and Parasitology, School of Medical Sciences, Universiti Sains Malaysia Health Campus, \\ 16150 Kubang Kerian, Kelantan,Malaysia \\ ${ }^{2}$ Epidemiology and Infection Control Unit, Hospital Universiti Sains Malaysia, 16150 Kubang Kerian, Kelantan, Malaysia
}

\begin{abstract}
Background: Melioidosis is an important public health problem causing community acquired sepsis in the northeastern part of Malaysia. Methodology: From January 2001 to December 2005, we reviewed case reports of all bacteraemic melioidosis admitted to a tertiary teaching hospital, Hospital Universiti Sains Malaysia.

Results: Thirty-five patients had positive blood culture for meliodosis and 27 case reports were traceable for further analysis. The mean age was $46.8+20.0$ years. Twenty patients $(74.1 \%)$ were male. The main clinical presentation was fever that occurred in $23(85.2 \%)$ patients. Eighteen patients $(66.7 \%)$ had lung involvement and three patients had liver abscess. Two patients presented with scrotal swelling, one of whom further developed Fournier's Gangrene. Nineteen $(70.4 \%)$ patients had underlying diabetes, five of whom were newly diagnosed during the admission. Thirteen (48.1\%) patients were treated with high-dose ceftazidime and six $(22.2 \%)$ patients were treated with imipenem. Eight (29.6\%) patients were not given anti-melioidosis therapy because the causative agents were not identified until after the patients died. The patients were admitted 16.8 days +18.1 . Seventeen patients $(63.0 \%)$ died in this series, 13 patients of whom died within four days of admission.

Conclusions: The wide range of clinical presentations and the fatal outcomes of melioidosis require a high level of suspicion among physicians to develop an early appropriate therapy and reduce the mortality rate.
\end{abstract}

Key words: melioidosis, clinical features, Malaysia

J Infect Dev Ctries 2010; 4(7):430-435.

(Received 12 September 2009 - Accepted 7 April 2010)

Copyright $\odot 2010$ Mohd Noor et al. This is an open-access article distributed under the Creative Commons Attribution License, which permits unrestricted use, distribution, and reproduction in any medium, provided the original work is properly cited.

\section{Introduction}

Melioidosis is a tropical infectious disease caused by Gram-negative bacteria Burkholderia pseudomallei. This soil-borne disease is endemic in southeast Asia and northern Australia. Melioidosis has a diverse spectrum of clinical presentation and can affect any organ. It is important to define the demographic profiles, clinical characteristics, and outcomes of melioidosis because of the regional differences that have been described in the prevalence of organ involvement $[1,2]$.

Kelantan State, which is located in the northeastern part of Malaysia, has a heavy monsoon season from November to March every year. This state is located in what is known as the Malaysian rice bowl and has more than 60,000 hectares of paddy fields [3]. Thousands of people are at risk of contracting $B$. pseudomallei, which is a great public health concern and an important cause of community acquired sepsis in the northeastern part of Malaysia.
However, not many publications on meliodosis come from Malaysia. This study aimed to determine the demographic profiles, clinical characteristics, and outcome of patients with bacteraemic melioidosis who attended Hospital Universiti Sains Malaysia, Kelantan.

\section{Materials and methods}

A retrospective study was performed in Hospital Universiti Sains Malaysia (HUSM) by reviewing the blood culture results from the years 2001 to 2005 using the WHO-net program. HUSM is an 800-bed tertiary teaching hospital that is located in Kelantan, a northeastern state of Malaysia.

All confirmed cases of bacteraemic melioidosis were selected for the study Bacteraemic melioidosis is defined as any positive blood culture for $B$. pseudomallei with or without sepsis. The patients' records were reviewed accordingly to determine the demographic profiles, clinical characteristics, and 
outcomes. Anti-melioidosis therapy for intensive phases used in HUSM during the study period was intravenous injection every eight hours of either 40 $\mathrm{mg} / \mathrm{kg}$ ceftazidime or $20 \mathrm{mg} / \mathrm{kg}$ imipenem. The use of other antimicrobial agents or the use of ceftazidime or imipenem below these suggested doses without renal dose adjustment was not considered antimelioidosis therapy. Death due to melioidosis was defined as a patient's death within 72 hours of blood culture positive for B. pseudomallei or a patient's clinical sepsis parameter that did not improve after the last blood culture positive for B. pseudomallei. Organ involvement of melioidosis was defined as present with clinical findings and/or investigative modalities of malfunctioning of that organ. The affected organ was probably the primary site of bacteraemia or its malfunction was a complication of bacteraemia. In HUSM, at least $5 \mathrm{ml}$ of blood were collected aseptically and inoculated into BACTEC $^{\mathrm{TM}}$ (Becton Dickinson, New Jersey, USA) blood culture bottles and incubated in the BACTEC $^{\mathrm{TM}}$ automated blood culture system. $B$. pseudomalle $i$ was identified by the growth of silverwhitish colonies on blood agar, was Gram negative, oxidase positive, produced a neutral-alkaline reaction on triple sugar iron, was motile, grew on $42^{\circ} \mathrm{C}$ and was colistin-resistant which were also confirmed by API NE $®$ system (bioMérieux, France).

Results were expressed in terms of the number and percentage or the mean \pm standard deviation. For categorical variables, the differences in patient characteristics and associated factors were tested by Chi-square and Fisher's exact test. For continuous variables, the independent t-test was used. The $p$ value of $\leq 0.05$ was considered significant. All analyses were done using SPSS software (SPSS, Chicago, Illinois, USA) in the Medical Informatics' Laboratory, School of Medical Sciences, Universiti Sains Malaysia.

\section{Results}

Out of 69,934 blood-culture request forms, 63 $(0.09 \%)$ were positive for $B$. pseudomallei coming from 35 patients. We managed to trace the case folders of 27 cases for further analysis (Table 1). The mean age was $46.8 \pm 20.0$ years. The youngest was 15 days old and the eldest was 80 years old. Twenty patients $(74.1 \%)$ were male. Fifteen $(55.6 \%)$ patients presented during the northeast monsoon rainy season. Only one patient's work was directly related to gardening soil.
The main clinical presentation was fever that occurred in $23(85.2 \%)$ patients. Eighteen patients $(66.7 \%)$ had lung involvement and three patients had liver abscess. Two patients presented with scrotal swelling, one of whom further developed Fournier's Gangrene. The mean total white cell count during admission was $15.8 \pm 7.5 \times 10^{3}$ cell $/ \mathrm{mL}$. Seven patients had normal total white cell counts during presentation and five of them died.

Nineteen (70.4\%) patients had underlying diabetes, five of whom were newly diagnosed during the admission. Four (14.8\%) patients had chronic renal diseases, and five patients had no identified underlying disease. One patient had underlying systemic lupus erythematosus.

For anti-melioidosis therapy, thirteen $(48.1 \%)$ patients were treated with high dose ceftazidime and six $(22.2 \%)$ patients were treated with imipenem. Eight $(29.6 \%)$ patients were not given antimelioidosis therapy because identification of the causative agents was not made until after the patient died. The patients were admitted for $16.8 \pm 18.1$ days.

Seventeen patients $(63.0 \%)$ died in this series of which 16 died directly due to bacteraemic melioidosis and 13 patients died within four days of admission. One of the patients (patient 11 in Table 1) was taken home against medical advice in an extremely ill state, failing to respond to imipenem. It is likely that this patient also died. This case was analyzed as death due to melioidosis.

In the association studies, death due to melioidosis among bacteraemic melioidosis was associated with shorter hospitalization, no identified underlying disease, and no anti-melioidosis therapy.

\section{Discussion}

There was no specific age for melioidosis. Neonatal melioidosis is not uncommon in Malaysia. The youngest case in this series was a 15-day-old boy who presented with abdominal distention and shock. Our centre had reported one case of neonatal meningitis due to B. pseudomallei in 1998 [4]. Another reported case of neonatal melioidosis in Malaysia was from the east coast state of Pahang in 2005 [5]. A case series of paediatric melioidosis in Kuala Lumpur reported one case of bacteraemic melioidosis in a neonate [6]. The baby was admitted for neonatal sepsis with fatal outcome.

We agree with the previous report from Kuala Lumpur that the correlation of melioidosis and rainfall is less strong in Malaysia compared to that in 
Table 1. Summary of bacteraemic melioidosis cases in Hospital Universiti Sains Malaysia from January 2001-December 2005

\begin{tabular}{|c|c|c|c|c|c|c|c|c|c|c|}
\hline No & $\begin{array}{c}\text { Age } \\
\text { (year) }\end{array}$ & Gender & Occupation & $\begin{array}{l}\text { Month of } \\
\text { admission }\end{array}$ & Presentation & $\begin{array}{c}\text { Organ } \\
\text { Involvement }\end{array}$ & Associated illness & $\begin{array}{c}\text { TWC on } \\
\text { admission }\end{array}$ & $\begin{array}{c}\text { Antibiotic therapy } \\
\text { for intensive } \\
\text { phase }\end{array}$ & Outcome \\
\hline 1 & 45 & Male & $\begin{array}{l}\text { Working } \\
\text { at rice mill }\end{array}$ & October & $\begin{array}{c}\text { Fever } \\
\text { Abdominal } \\
\text { distention Jaundice } \\
\text { Fever }\end{array}$ & Lung & $\begin{array}{c}\text { DM } \\
\text { Renal failure }\end{array}$ & 8.0 & Ceftazidime & $\begin{array}{l}\text { Died due to } \\
\text { melioidosis }\end{array}$ \\
\hline 2 & 44 & Male & NA & July & $\begin{array}{l}\text { Neck cellulitis after } \\
\text { dental extraction }\end{array}$ & Soft tissue & $\mathrm{DM}$ & 18.2 & Ceftazidime & Recover \\
\hline 3 & 63 & Female & $\begin{array}{l}\text { Retired } \\
\text { teacher }\end{array}$ & July & Fever & Lung & DM & 12.8 & Imipenem & $\begin{array}{l}\text { Recovered } \\
\text { with relapse }\end{array}$ \\
\hline 4 & 54 & Female & Housewife & January & Admitted in shock & NA & $\begin{array}{c}\text { DM } \\
\text { Severe heart } \\
\text { valve problem }\end{array}$ & 16.2 & $\begin{array}{l}\text { No anti- } \\
\text { melioid } \\
\text { therapy }\end{array}$ & $\begin{array}{l}\text { Died due to } \\
\text { melioidosis }\end{array}$ \\
\hline 5 & 80 & Male & $\begin{array}{l}\text { Retired } \\
\text { teacher }\end{array}$ & December & $\begin{array}{c}\text { Fever } \\
\text { Weakness }\end{array}$ & Lung & No & 10.9 & $\begin{array}{l}\text { No anti- } \\
\text { melioid } \\
\text { therapy }\end{array}$ & $\begin{array}{l}\text { Died due to } \\
\text { melioidosis }\end{array}$ \\
\hline 6 & 61 & Male & Odd job & January & $\begin{array}{c}\text { Fever } \\
\text { Urinary retention }\end{array}$ & $\begin{array}{l}\text { Lung } \\
\text { Urinary } \\
\text { tract }\end{array}$ & DM & 13.4 & $\begin{array}{l}\text { No anti- } \\
\text { melioid } \\
\text { therapy }\end{array}$ & $\begin{array}{l}\text { Died due to } \\
\text { melioidosis }\end{array}$ \\
\hline 7 & 61 & Male & $\begin{array}{l}\text { Retired } \\
\text { staff }\end{array}$ & November & $\begin{array}{c}\text { Fever } \\
\text { Scrotum swelling }\end{array}$ & Lung & DM & 20.8 & Imipenam & Recovered \\
\hline 8 & 52 & Male & Policeman & December & $\begin{array}{l}\text { Fever } \\
\text { Cough }\end{array}$ & Lung & DM & 15.0 & Ceftazidime & $\begin{array}{l}\text { Died due to } \\
\text { melioidosis }\end{array}$ \\
\hline 9 & 56 & Female & $\begin{array}{l}\text { Retired } \\
\text { staff }\end{array}$ & December & $\begin{array}{l}\text { Fever } \\
\text { Cough }\end{array}$ & Lung & $\begin{array}{l}\text { Chronic liver } \\
\text { disease }\end{array}$ & 16.8 & $\begin{array}{l}\text { No anti- } \\
\text { melioid } \\
\text { therapy }\end{array}$ & $\begin{array}{l}\text { Died due to } \\
\text { meliodosis }\end{array}$ \\
\hline 10 & 38 & Male & Policeman & June & Seizures & Lung & $\begin{array}{l}\text { DM - newly } \\
\text { diagnosed }\end{array}$ & 28.2 & Ceftazidime & Recovered \\
\hline 11 & 25 & Female & Gardener & June & Fever & NA & No & 40.7 & Imipenem & $\begin{array}{l}\text { Died due to } \\
\text { melioidosis* }\end{array}$ \\
\hline 12 & 12 & Female & Student & January & $\begin{array}{l}\text { Fever } \\
\text { Seizures }\end{array}$ & Brain & $\begin{array}{c}\text { SLE } \\
\text { Lupus nephritis }\end{array}$ & 7.7 & Imipenem & $\begin{array}{l}\text { Died due to } \\
\text { melioidosis }\end{array}$ \\
\hline 13 & 62 & Male & NA & September & $\begin{array}{l}\text { Fever } \\
\text { Cough }\end{array}$ & Lung & DM & 5.6 & $\begin{array}{l}\text { No anti- } \\
\text { melioid } \\
\text { therapy }\end{array}$ & $\begin{array}{l}\text { Died due to } \\
\text { melioidosis }\end{array}$ \\
\hline 14 & 75 & Female & NA & March & $\begin{array}{l}\text { Lethargy } \\
\text { Vomiting }\end{array}$ & Lung & $\begin{array}{l}\mathrm{DM} \\
\mathrm{CRF}\end{array}$ & 4.3 & Caftazidime & $\begin{array}{c}\text { Died due to } \\
\text { upper gastro- } \\
\text { intestinal bleed } \\
\text { and } \\
\text { nosocomial } \\
\text { sepsis }\end{array}$ \\
\hline 15 & 46 & Male & NA & February & $\begin{array}{c}\text { Fever } \\
\text { Abdominal pain }\end{array}$ & Lung & DM & 25.3 & Ceftazidime & $\begin{array}{l}\text { Died due to } \\
\text { melioidosis }\end{array}$ \\
\hline 16 & 60 & Male & NA & September & $\begin{array}{c}\text { Fever } \\
\text { Cough } \\
\text { Diarrhea } \\
\text { Abdominal pain }\end{array}$ & Lung & $\begin{array}{l}\text { DM - newly } \\
\text { diagnosed }\end{array}$ & 18.1 & Ceftazidime & $\begin{array}{l}\text { Died due to } \\
\text { melioidosis }\end{array}$ \\
\hline
\end{tabular}


Table 1. Continued

\begin{tabular}{|c|c|c|c|c|c|c|c|c|c|c|}
\hline No & $\begin{array}{c}\text { Age } \\
\text { (year) }\end{array}$ & Gender & Occupation & $\begin{array}{c}\text { Month of } \\
\text { admission }\end{array}$ & Presentation & $\begin{array}{c}\begin{array}{c}\text { Organ } \\
\text { Involvement }\end{array} \\
\text { tol }\end{array}$ & Associated illness & $\begin{array}{c}\text { TWC on } \\
\text { admission }\end{array}$ & $\begin{array}{l}\text { Antibiotic therapy } \\
\text { for intensive } \\
\text { phase }\end{array}$ & Outcome \\
\hline 17 & 70 & Male & $\begin{array}{l}\text { Retired } \\
\text { staff }\end{array}$ & August & $\begin{array}{c}\text { Fever } \\
\text { Scrotal swelling }\end{array}$ & Soft tissue & DM & 19.5 & Ceftazidime & Recovered \\
\hline 18 & $1 \#$ & Male & - & December & $\begin{array}{c}\text { Abdominal } \\
\text { distention Shock }\end{array}$ & NA & No & 15.7 & $\begin{array}{l}\text { No antimelioid } \\
\text { therapy }\end{array}$ & $\begin{array}{l}\text { Died due to } \\
\text { melioidosis }\end{array}$ \\
\hline 19 & 49 & Male & $\begin{array}{l}\text { Retired } \\
\text { army }\end{array}$ & June & $\begin{array}{c}\text { Fever } \\
\text { Epigastric pain } \\
\text { Jaundice }\end{array}$ & $\begin{array}{l}\text { Lung } \\
\text { Liver }\end{array}$ & $\begin{array}{l}\text { DM - newly } \\
\text { diagnosed }\end{array}$ & 12.8 & Imipenem & $\begin{array}{l}\text { Died due to } \\
\text { melioidosis }\end{array}$ \\
\hline 20 & 62 & Female & NA & October & $\begin{array}{l}\text { Fever } \\
\text { Cough }\end{array}$ & Lung & No & 12.4 & $\begin{array}{l}\text { No anti- } \\
\text { melioid } \\
\text { theranv }\end{array}$ & $\begin{array}{l}\text { Died due to } \\
\text { melioidosis }\end{array}$ \\
\hline 21 & 56 & Male & NA & November & $\begin{array}{c}\text { Fever } \\
\text { Left leg swelling } \\
\text { Multiple skin } \\
\text { abscess }\end{array}$ & $\begin{array}{l}\text { Lung } \\
\text { Skin }\end{array}$ & DM & 16.7 & Ceftazidime & $\begin{array}{c}\text { Recovered } \\
\text { with relapse }\end{array}$ \\
\hline 22 & 5 & Male & - & November & $\begin{array}{c}\text { Fever } \\
\text { Diarrhoea } \\
\text { Vomiting }\end{array}$ & NA & No & 20.2 & $\begin{array}{l}\text { No anti- } \\
\text { melioid } \\
\text { therapy }\end{array}$ & $\begin{array}{l}\text { Died due to } \\
\text { melioidosis }\end{array}$ \\
\hline 23 & 41 & Male & NA & October & Fever & $\begin{array}{l}\text { Liver } \\
\text { Soft tissue } \\
\text { Skin }\end{array}$ & $\begin{array}{l}\text { DM - newly } \\
\text { diagnosed }\end{array}$ & 14.6 & Ceftazidime & Recovered \\
\hline 24 & 34 & Male & $\begin{array}{l}\text { Sea diver } \\
\text { instructor }\end{array}$ & November & Fever & $\begin{array}{l}\text { Liver } \\
\text { Spleen }\end{array}$ & $\begin{array}{l}\text { DM - newly } \\
\text { diagnosed }\end{array}$ & 8.6 & Ceftazidime & Recovered \\
\hline 25 & 40 & Male & Laborer & March & $\begin{array}{c}\text { Fever } \\
\text { Nausea } \\
\text { Vomiting } \\
\text { Jaundice }\end{array}$ & $\begin{array}{l}\text { Lung } \\
\text { Right hip } \\
\text { joint }\end{array}$ & $\begin{array}{l}\mathrm{DM} \\
\mathrm{CRF}\end{array}$ & 19.9 & Ceftazidime & $\begin{array}{l}\text { Died due to } \\
\text { melioidosis }\end{array}$ \\
\hline 26 & 48 & Male & NA & April & $\begin{array}{l}\text { Fever } \\
\text { Cough }\end{array}$ & Lung & DM & 10.8 & Imipenem & Recovered \\
\hline 27 & 24 & Male & $\begin{array}{l}\text { Assistant } \\
\text { engineer }\end{array}$ & November & $\begin{array}{c}\text { Fever } \\
\text { Nausea } \\
\text { Vomiting }\end{array}$ & Lung & CRF & 13.6 & Ceftazidime & Recovered \\
\hline
\end{tabular}

Thailand and in northern Australia [7]. We found that months of presentation were not significant association of mortality due to melioidosis. We also found that the occupation of bacteraemic melioidosis patients was not necessarily related to soil. Only one patient was working as a gardener. One other patient worked in a rice mill. This is in contrast with a previous study in Thailand that found that more than half of melioidosis patients were paddy farmers $[8,9]$. As in other studies on melioidosis [2,6,8-10], men were predominantly affected, perhaps because they were more frequently exposed to soil and water.

Fever was the most common clinical presentation; however, absence of fever during presentation was observed in four patients. High total white cell counts were present in many bacterial infections but we observed normal total white cell counts in seven patients although they had severe sepsis; nevertheless, these two factors were not significantly associated with mortality in associated studies. Other presentations included cough, scrotal swelling, Fournier's Gangrene, urinary retention, neck cellulitis, abdominal distention, jaundice, vomiting, and seizures. The wide diversity of clinical syndromes are known phenomena in melioidosis [11].

Nineteen patients $(70.4 \%)$ had underlying diabetes in this series, five of whom were newly diagnosed during the admission. Puthucheary et al. reported only $28 \%$ of the patients in their study with diabetes [12]. Undiagnosed diabetes mellitus is an occult risk factor of melioidosis and the patient might 
Table 2. Selected associated factors of mortality among bacteraemic melioidosis patient

\begin{tabular}{|c|c|c|c|}
\hline Variable & $\begin{array}{c}\text { Died due to bacteraemic } \\
\text { melioidosis } \\
\mathrm{N}=16 \\
\text { Mean }(\mathrm{sd}) * / \text { Freq }(\%)\end{array}$ & $\begin{array}{c}\text { Recovered or died due to } \\
\text { other causes } \\
\mathrm{N}=11 \\
\text { Mean }(\mathrm{sd}) \text { / Freq }(\%)\end{array}$ & $p$ value ${ }^{\#}$ \\
\hline \multicolumn{4}{|l|}{ Gender } \\
\hline Male & $11(68.8)$ & $9(81.8)$ & $0.446^{\mathrm{a}}$ \\
\hline Female & $5(31.3)$ & $2(18.2)$ & \\
\hline Age (years) & $44.4(22.5)$ & $50.1(16.0)$ & $0.455^{\mathrm{b}}$ \\
\hline \multicolumn{4}{|l|}{ Month of presentation } \\
\hline Dry & $6(37.5)$ & $6(55.5)$ & \multirow{2}{*}{$0.381^{\mathrm{a}}$} \\
\hline Rainy & $10(62.5)$ & $5(45.5)$ & \\
\hline $\begin{array}{l}\text { Length of hospital stay } \\
\text { (days) }\end{array}$ & $3.1(2.3)$ & $36.7(10.4)$ & $<0.001^{\mathrm{b}}$ \\
\hline $\begin{array}{l}\text { Fever during } \\
\text { presentation }\end{array}$ & $14(87.5)$ & $9(81.8)$ & $0.683^{\mathrm{a}}$ \\
\hline $\begin{array}{l}\text { Total white count } \\
\text { during admission }\end{array}$ & $16.2(8.3)$ & $15.3(6.5)$ & $0.769^{\mathrm{b}}$ \\
\hline Lung involvement & $11(68.8)$ & $7(63.6)$ & $0.782^{\mathrm{a}}$ \\
\hline $\begin{array}{l}\text { Underlying disease } \\
\text { identify }\end{array}$ & $11(68.8)$ & $11(100.0)$ & $0.014^{\mathrm{c}}$ \\
\hline $\begin{array}{l}\text { Anti-melioidosis } \\
\text { therapy given }\end{array}$ & $8(50.0)$ & $11(100.0)$ & $0.001^{\mathrm{c}}$ \\
\hline $\begin{array}{l}\text { p value significant at } 0.05 \\
\text { Pearson chi square }\end{array}$ & $\begin{array}{l}\text {-test } \\
\text { test }\end{array}$ & & \\
\hline
\end{tabular}

present very severe sepsis. In the present study, two out of five patients with newly diagnosed diabetes mellitus died. Renal disease was another risk factor identified in four patients with bacteraemic melioidosis. Five patients had no identified underlying disease.

The pulmonary involvement in this study $(66.7 \%)$ was higher than that in previous cases from Kuala Lumpur (58\%) [12]. Another series from Australia reported $60 \%$ of pulmonary involvement among bacteraemic melioidosis patients [13]. The liver and spleen were also common sites for abscess formation. Liver and/or spleen abscess were also reported as the most common sites for extrapulmonary infection in Thailand [9]. In this series, we found three cases of liver abscess and one case of splenic abscess. Involvement of the brain is in the form of brain abscess $[14,15]$. We found one case of possible cerebral melioidosis, but the patient died before proper diagnostic work was commenced.

The mortality rate was very high. There was not much difference in the mortality rate in this series when compared to the previous report in 1992 (65\%) [12]. Thirteen of the deaths occurred within four days of admission. The patients died before the laboratory was able to confirm the causative organism. This condition was significantly associated with mortality in this series.
From the results of this study, we suggest that, in an endemic area such as our region, melioidosis should always be included as a working diagnosis in cases presenting with community-acquired infection even if the patient has no underlying medical illness. Low index of suspicion in cases with unidentified underlying diseases puts the patient at risk of not getting proper anti-melioidosis treatment. This study found that anti-melioidosis therapy was given to only one of the patients who had no identified underlying diseases.

Lack of clinical suspicion leading to delay in treatment is well described in other studies. Only one out of seven $(14.3 \%)$ paediatric bacteraemic melioidosis patients was treated empirically with active drugs for melioidosis in Pahang, Malaysia [16]. There were better findings in Singapore where 43.3\% bacteraemic melioidosis patients had initial empiric antibiotic therapy that was appropriate for melioidosis [13]. This is in contrast with the study in Australia that found no fatal cases among patients with no identified underlying illness [10] who were treated empirically with active drugs for melioidosis.

As stated above, thirteen patients died within four days of admission. We were able to identify five cases of newly diagnosed diabetes mellitus presenting with melioidosis. It was unfortunate that these patients died before a proper, full laboratory 
investigation was done, and as a result, these cases were categorized as having no identified medical illness. The bottom line is that a higher index of suspicion of melioidosis among physicians is very important, even in patients with no identified underlying diseases.

In this study, $20.0 \%$ of the surviving patients suffered a relapse. Currie et al. reported a $13.0 \%$ relapse in a greater number of patients with $2.4 \%$ of patients relapsing twice [17]. Relapse can be due to poor compliance with eradication therapy, failure of eradication therapy, inadequate intensive therapy, reinoculation from bone flap re-implant, chronic $B$. pseudomallei carriage, and new infection [17].

In conclusion, this review shows the importance of a high index of suspicion among physicians in order to provide early therapy and reduce the mortality rate among melioidosis patients.

\section{Acknowledgement}

We would like to thank the Universiti Sains Malaysia for providing us with the Incentive Grant to complete the study.

\section{References}

1. White NJ (2003) Melioidosis. Lancet 361: 1715-1722.

2. Malczewski $A B$, Oman KM, Norton RE, Ketheesan $\mathrm{N}$ (2005) Clinical presentation of melioidosis in Queensland, Australia. Trans R Soc Trop Med Hyg 99: 856-860.

3. Department of Agriculture Annual Report, (2001) Kuala Lumpur, Malaysia.

4. Halder D, Zainal N, Wah CM, Haq JA (1998) Neonatal meningitis and septicaemia caused by Burkholderia pseudomallei. Ann Trop Paediatr 18: 161-164.

5. Ang YM (2005) Neonatal meliodosis: very rare but be aware. Med J Malaysia 60: 99-102.

6. Sam IC and Puthucheary SD (2006) Melioidosis in children from Kuala Lumpur, Malaysia. Ann Trop Paediatr 26: 219224.

7. Sam IC and Puthucheary SD (2007) Melioidosis and rainfall in Kuala Lumpur, Malaysia. J Infect 54: 519-520.

8. Suputtamongkol Y, Chaowagul W, Chetchotisakd P, Lertpatanasuwun N, Intaranongpai $\mathrm{S}$, Ruchutrakool $\mathrm{T}$,
Budhsarawong D, Mootsikapun P, Wuthiekanun V, Teerawatasook N, Lulitanond A (1999) Risk factors for melioidosis and bacteremic melioidosis. Clin Infect Dis 29: 408-413.

9. Reechaipichitkul W (2004) Clinical manifestation of pulmonary melioidosis in adults. Southeast Asian J Trop Med Public Health 35: 664-669.

10. Currie BJ, Jacups SP, Cheng AC, Fisher DA, Anstey NM, Huffam SE, Krause VL (2004) Melioidosis epidemiology and risk factors from a prospective whole-population study in northern Australia. Trop Med Inter Health 9: 1167-1174.

11. Dance DA (1991) Melioidosis: the tip of the iceberg? Clin Microbiol Rev 4: 52-60.

12. Puthucheary SD, Parasakthi N, Lee MK (1992) Septicaemic melioidosis: a review of 50 cases from Malaysia. Trans $\mathrm{R}$ Soc Trop Med Hyg 86: 683-685.

13. Mukhopadhyay A, Lee KH, Tambyah PA (2004) Bacteraemic melioidosis pneumonia: impact on outcome, clinical and radiological features. J Infect 48: 334-338.

14. Padiglione A, FerrisN, Fuller A, Spelman D (1998) Brain abscesses caused by Burkholderia pseudomallei. J of Infect 36: 335-337.

15. Chadwick DR, Ang B, Sitoh YY, Lee CC (2002) Cerebral melioidosis in Singapore: a review of five cases. Trans $\mathrm{R}$ Soc Trop Med Hyg 96: 72-76.

16. How HS, Ng KH, Yeo HB, Tee HP and Shah A (2005) Pediatric melioidosis in Pahang, Malaysia. J Microbiol Immunol Infect 38: 314-319.

17. Currie BJ, Fisher DA, Anstey NM, Jacups SP (2000) Melioidosis: acute and chronic disease, relapse and reactivation. Trans R Soc Trop Med Hyg 94: 301-304.

\section{Corresponding Author}

Mohd Noor Siti Suraya

Department of Medical Microbiology and Parasitology,

School of Medical Sciences,

Universiti Sains Malaysia Health Campus,

16150 Kubang Kerian, Kelantan,

Malaysia

email: ssuraiya@kck.usm.my

Conflict of interests: No conflict of interests is declared. 